\title{
The implications of herd entrustment practice for the sustainable use of cattle genetic resources in the (agro)-pastoral systems of West Africa: A case study from Benin
}

\author{
Sèyi Fridaïus Ulrich Vanvanhossou ${ }^{1,2}$, Ivan Bossima Koura ${ }^{3}$ and Luc Hippolyte Dossa ${ }^{1 *}$ (i)
}

\begin{abstract}
West African (agro)-pastoralists have been increasingly using extra-household labour for the management of their cattle herds. This paper seeks to identify the factors influencing cattle owners' decision to entrust their animals and to analyse the effects of the entrustment practice on the management and sustainable use of the animal genetic diversity within herds. Two hundred and eleven cattle farmers, including absentee-owners $(n=90)$ who entrusted their animals to professional herders, and owner-managers $(n=121)$ who look themselves after their cattle, were randomly selected and surveyed in Boukombe district in northwest Benin, the origin of the West African shorthorn Somba cattle breed. Households' socio-economic data and information on herds' characteristics and management practices were collected using semi-structured questionnaires. The binary logistic regression technique was used to predict the adoption of entrustment by a given farmer in function of his herd's and household's socio-economic characteristics. Effective population sizes and inbreeding rates for the communal non-entrusted and entrusted Somba populations were estimated and compared. The results revealed that the mode of acquisition of the initial stock, the total livestock units owned and the farmer's ethnicity were the most important determinants of entrustment. The Somba indigenous cattle breed was threatened in entrusted herds by indiscriminate cross-breeding with Zebus. However, the non-entrusted population appeared to be more exposed to high inbreeding risks. While entrustment represents a good alternative for the efficient use of family labour, adequate strategies are needed to support this practice and encourage herd managers to adopt improved husbandry practices and sound breeding strategies.
\end{abstract}

Keywords: Bovine genetic diversity, Cross-breeding, Herd management, Indigenous breeds, Labour, Pastoralism

\section{Introduction}

African pastoral systems are increasingly shaped by entrustment and herding contracts which are arrangements between an owner and a herder who cares for the herd against remuneration (Moritz et al. 2015). However, few

\footnotetext{
* Correspondence: hippolyte.dossa@fsa.uac.bj; dolhip@yahoo.com 'Ecole des Sciences et Techniques de Production Animale Faculté des Sciences Agronomiques, Université d'Abomey-Calavi, 03 BP 2819, Cotonou, Benin

Full list of author information is available at the end of the article
}

differences exist between these two arrangements. Hired herding is a labour contract in which an owner pays a herder a monthly wage and provides him with herding equipment (shoes, clothes, stick) whereas entrustment is a leasing contract in which an owner places his animals with a herder who looks after them and has usufruct rights over milk but is not paid a wage, although there may be other forms of compensation, including cash (Turner 1999; Moritz 2012a). Moritz et al. (2011) also argued that when animals are entrusted, the herder has 
a personal interest in their welfare and that this is not the case for animals placed with a hired herder. But, since both practices refer to the use by households of extra-household labour force or "non-family labour" for tending the stock, we will further in this paper use the term "entrustment" to design both practices.

Cattle herd entrustment is particularly widespread in the West African region (Tonah 2012; Dafinger 2013; Breusers 2014; Koffi et al. 2017) and is established in a wide variety of circumstances, and under many different terms (Turner and Hiernaux 2008; Turner et al. 2014; Moritz et al. 2015). In addition to allowing farmers to allocate more labour to their crop farming activities (Little 1992; Oksen 2001), especially when labour costs are high (Nin-Pratt et al. 2010), entrusting the management of their cattle herds to kinsmen or to hired herders helps them make their accumulated wealth in animals invisible to their fellow kin (Lont and Hospes 2004; Dafinger 2013). Likewise, a successful entrustment favours both the establishment and the strengthening of social relationships (Breusers 2014). Yet, according to several authors, this practice is fraught with many disadvantages. Moritz (2012b) identifies the risk of animal losses owing to theft and/or herder negligence as the greatest disadvantage. According to Dafinger (2013), entrusting cattle is a highly complex procedure that requires a great degree of trust. Duguma et al. (2012) also mention the deprivation of the owner from access to milk and milk products. Despite these drawbacks, cattle entrustment is growing in importance in the African pastoral systems (Toulmin 1992; Turner and Hiernaux 2008; Moritz et al. 2011).

The implication of this practice for the conservation and sustainable use of indigenous farm genetic resources has been largely overlooked in previous studies. In both cattle entrusting and herding contracts systems, farmers entrust their animals or entire herds to individuals of the Fulani ethnic group whose identity is linked to animal husbandry. Yet, traditionally, Fulani herders are strongly attached to humped cattle, commonly called Zebus, (Boutrais 2007). Therefore, this practice could contribute to the replacement in some herds of locally adapted but very often perceived as low milk-producing humpless cattle breeds with Zebus. This is especially evident when the large share of the milk goes to the herders as part of their remuneration. Blench (1999) has considered this practice as one of the major factors contributing to the decline of the Muturu cattle, a shorthorn cattle in Nigeria, along with widespread indiscriminate crossbreeding that threatens indigenous cattle breeds in several African countries (Wollny 2003; FAO 2015; Mwai et al. 2015). Indiscriminate cross-breeding refers to "a spectrum of actions ranging from upgrading or crossbreeding to complete replacement of a local breed with imported animal genetic resources in an unplanned manner and without adequate assessment of the performance of the respective breeds under relevant production conditions" (FAO 2007). Investigating the relation between the practice of entrustment and the sustainable use of genetic resources within herds is therefore of great interest. Article 2 of the Convention on Biological Diversity (UNEP 1992) defines sustainable use as "the use of components of biological diversity in a way and at a rate that does not lead to the long-term decline of biological diversity, thereby maintaining its potential to meet the needs and aspirations of present and future generations". Such needs and aspirations not only include economical aspects but also socio-cultural and environmental importance of animal genetic resources (Rege and Gibson 2003; Nimbkar et al. 2008). Indeed, ensuring that locally adapted breeds remain a functional part of production systems is valuable, especially in the current context of climate change (FAO 2007).

In the northwest Benin, the humpless West African shorthorn Somba cattle (Fig. 1) traditionally kept in smallholdings in family-managed herds (Fig. 2a) has been increasingly entrusted to Fulani herders (Fig. 2b, Dossa and Vanvanhossou 2016). According to Hall et al. (1995), the Somba breed constitutes the residue of the original ancestral population of West African shorthorn preserved from admixture until recent years in Boukombe in Benin - see later for details. While Dossa and Vanvanhossou (2016) observed no exchange of reproducers between entrusted and family-managed herds, Hindar (2001) and Kamuanga et al. (2006) reported breeding practices and indiscriminate cross-breeding as the major factors inducing the reduction of the Somba cattle population. Nevertheless, local farmers have expressed their willingness to maintain this breed which they prefer over other breeds for its several attributes including milk and meat taste, keeping easiness, tolerance to disease, tolerance to feed and to water shortage and reproductive performances (Dossa and Vanvanhossou 2016). Therefore, by taking the Somba breed as an example, this research aimed to (i) identify and analyse the key factors determining the adoption of herd entrustment to Fulani herders by autochthonous cattle farmers and to (ii) establish the relation between this practice and the conservation and rational use of local farm animal genetic resources.

\section{Conceptual framework}

The agricultural household model has been frequently used to study household's labour allocation, including its demand for extra-household labour (Blanc et al. 2008; Bagamba et al. 2009; Bedemo et al. 2013). In the current situation where heads of households tend to be the decision-makers regarding the household's cattle herd management and labour allocation in northern Benin 


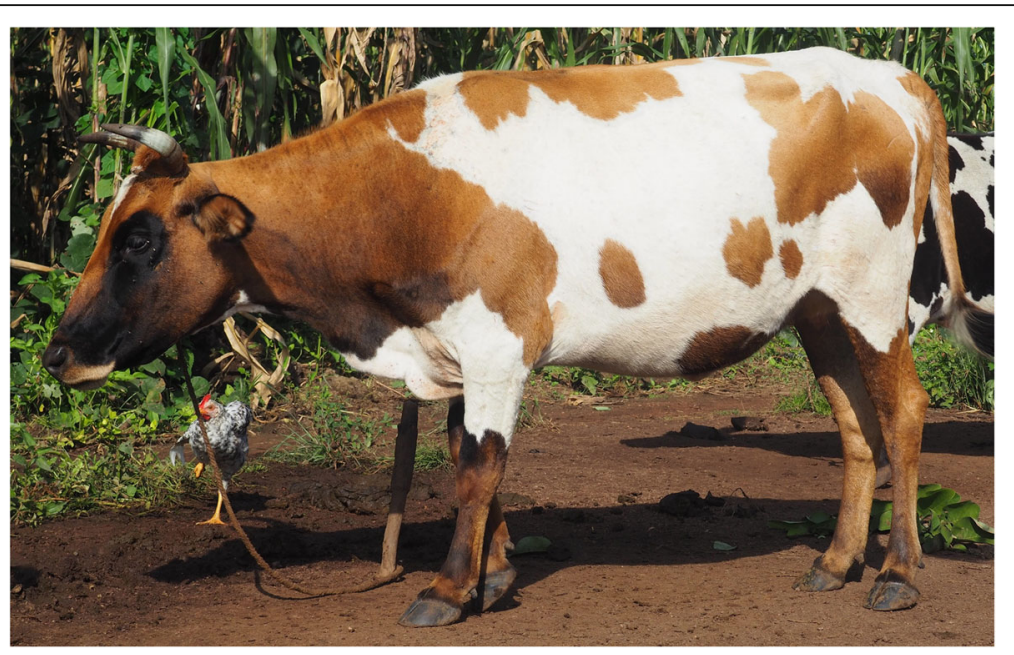

Fig. 1 Photo of Somba cattle

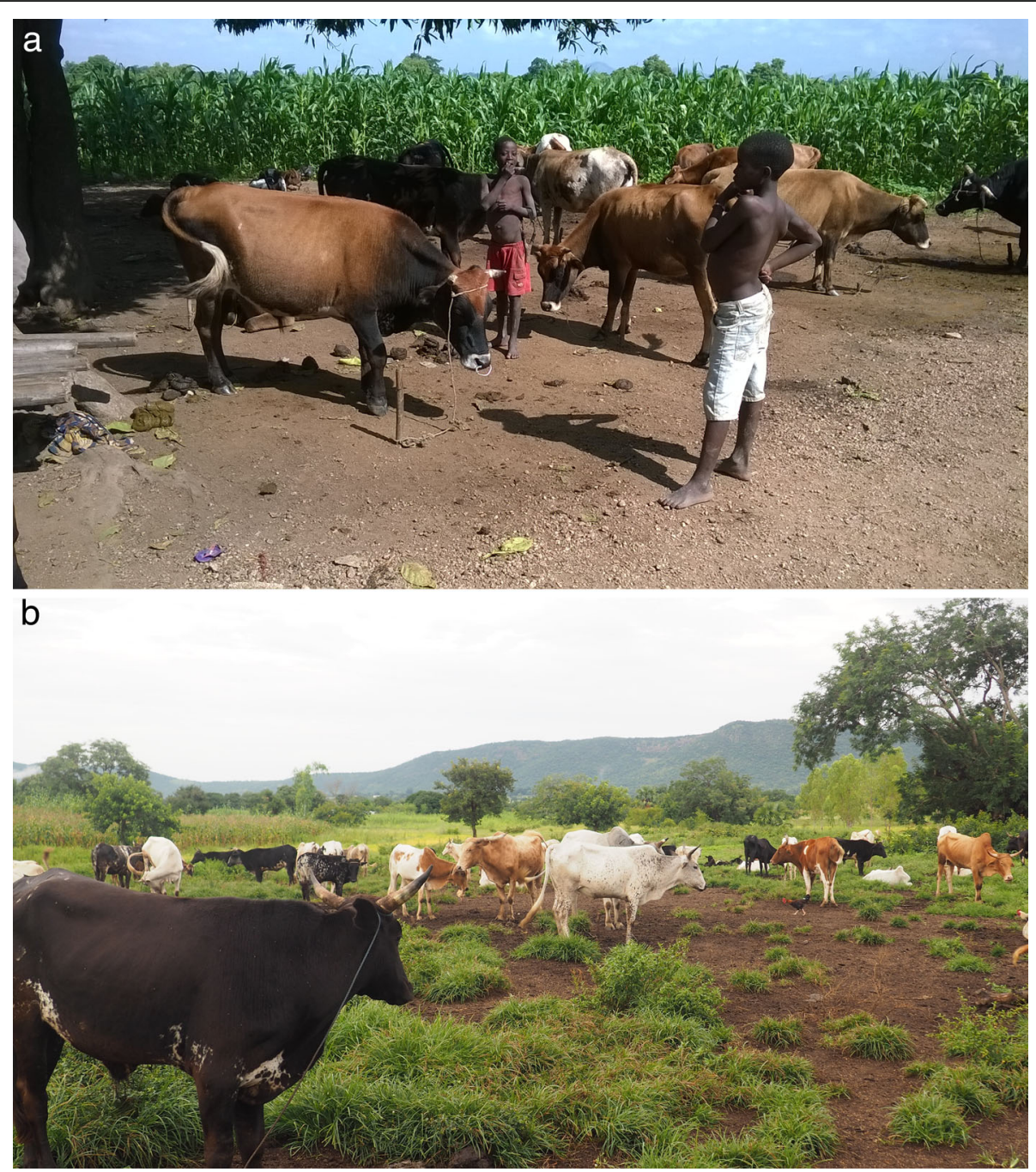

Fig. 2 Owner-managed Somba herd (a). Entrusted Somba herd with Zebu and cross-breeds (b) 
(De Haan 1997), a reduced form of the agricultural household model that only represents the decisions of the head of household (Donnellan et al. 2012) seems to be more suitable. We have drawn explanatory variables from previous empirical studies on the decisions to use extra-household labour or hired labour by smallholder farmers.

A number of studies (Benjamin et al. 1996; Benjamin and Kimhi 2006; Blanc et al. 2008; Omotesho et al. 2014) have pointed out the importance of family size in smallholder farmer labour allocation decisions. Assuming that family and hired labour are perfect substitutes (up to a scale) on the farm, Blanc et al. (2008) observed that the higher the total household size, the more available is the family labour and hence the lesser is the need for hired labour. Similar observations were made by Bedemo et al. (2013) and Omotesho et al. (2014). But as pointed out by Roumasset and Lee (2007), family labour and non-family labour will significantly differ in both tasks and skills and are therefore not perfect substitutes. Results of the study by Darpeix et al. (2014) found family labour to be more substitutable for seasonal than permanent hired labour.

Significant negative relationships between family composition and use of hired labour were also reported (Benjamin et al. 1996; Benjamin and Kimhi 2006; Blanc et al. 2008; Bedemo et al. 2013; Omotesho et al. 2014). That is, the more adults in the household, the more labour it can supply both on- and off-farm and the less likely the household hires labour.

The head of farm household's level of education (Omotesho et al. 2014; Benjamin et al. 1996; Benjamin and Kimhi 2006; Blanc et al. 2008) as well as his main source of income was also observed to affect his decision to use hired labour. Murphy (2015) reported that cattle owners who do not depend on their herds as the major source of income were more likely to entrust their management to hired herders.

Among the farm characteristics, farm size was reported to significantly and positively affect hired labour use (Bagamba et al. 2009; Dupraz et al. 2010). Hence, when a household is involved in both crop production and cattle raising, one could expect that the larger the household's cultivated cropland, the higher its likelihood to entrust its cattle herd to hired herders. Toulmin (1992) argued that, in such a context, the cost of hiring labour for herding is much less than a man's grain production in an average year. Likewise, Moritz et al. (2011) reported a positive relationship between the size of the cattle herd and the need for extra-household labour in the Far North Region of Cameroon. It is thus expected that the larger its cattle herd size, the greater the probability that a household requires extra-household labour to look after its animals.
In summary, potential factors affecting the decision to use agricultural extra-household labour are diverse and may include the size and composition (age, sex) of the family, the household head's educational level and main activity as well as the farm or herd size.

\section{Study area}

The study was conducted in Boukombe district, the original habitat of the Somba cattle breed kept around the Atacora mountain area in northwest Benin, West Africa. The Boukombe region lies between latitudes $10^{\circ} 00^{\prime}$ and $10^{\circ} 40^{\prime}$ North and longitudes $0^{\circ} 75^{\prime}$ and $1^{\circ} 30^{\prime}$ East. The area has two seasons, one dry season (NovemberMarch) and one rainy season (April-October) with an average annual rainfall of $1000 \mathrm{~mm}$ and a temperature ranging from 24 to $36^{\circ} \mathrm{C}$. In spite of the dominance of rocky soils in this region, crop production is the main activity for farmers followed by livestock keeping and off-farm activities (Adégbidi et al. 2004).

The major cash crops are tobacco (Nicotiana tabacum) and cotton (Gossypium spp.) while sorghum (Sorghum bicolor), millet (Pennisetum glaucum), fonio millet (Digitaria exilis), rice (Oryza sativa), corn (Zea mays), cowpea (Vigna unguiculata), peanut (Arachis hypogea), yam (Dioscorea spp.) and potato (Ipomoea batatas) are the main cultivated food crops. Livestock keeping, in addition to cattle, includes mainly goat, pigs and poultry. Common cattle breeds raised include the shorthorn taurine Somba cattle (humpless), Zebus (humped) and varieties of cross-breed between taurine and Zebus. The Somba cattle, indigenous to the area, are small-bodied with a relatively long and narrow head (Dossa and Vanvanhossou 2016). This breed is also known to be tolerant to trypanosomiasis, a parasitic disease transmitted by tsetse flies and endemic to the West African region (Berthier et al. 2016).

\section{Methods \\ Sampling procedure and data collection}

The two administrative units (arrondissements) of Boukombe and Korontiere were selected out of the total of seven composing the district of Boukombe, because together they hold $37.56 \%$ of the cattle population of the district (Gbaguidi et al. 2006). In contrast to Korontiere, the human population in Boukombe is dominated by autochthonous Otammari (INSAE 2016).

A total of fourteen villages (seven in each administrative unit) were included in the study. In Boukombe, a permission to conduct the survey was granted by the local authorities only in seven villages out of a total of seventeen, whereas all the seven villages composing Korontiere were included in the survey. The snowball sampling technique was used to select and interview a total of 122 livestock keepers in Korontiere and 102 in 
Boukombe, from May to July 2017. Out of 224 cattle farmers surveyed, 121 were owners who themselves kept their cattle (owner-managers), 90 were owners who entrusted their cattle (absentee-owners) and 13 were professional herders who kept entrusted cattle. Only data collected from owner-managers and absenteeowners were considered in the analysis of the determinants of cattle entrustment. Information on general household characteristics (household size, age and sex of household head, ethnicity, educational level, cattle keeping experience, off-farm employment, main source of income), cattle herd composition, management practices, practice of stock entrustment and practices of other agricultural activities (cultivated land size) was collected using a semi-structured questionnaire. In addition, farmers' explanations regarding their reasons to entrust or not their cattle were recorded and used to discuss the results of statistical analyses. The identification of animal breeds (Somba, cross-breed, Borgou, Zebu) was based on farmers' appreciations, considering animal history and phenotypic observations (Fig. 3a-c). Recently, Houessou et al. (2019) confirmed the accuracy of farmers' knowledge in distinguishing cattle breeds in Benin based on morphologic traits. In addition, recent genomic analyses showed very low admixture in animals identified by farmers and sampled as Somba cattle (Scheper et al. 2020).

\section{Data analysis}

\section{Predicting the determinant factors of cattle entrustment}

Firstly, exploratory bivariate analyses were carried out using chi-square and Mann-Whitney $U$ tests to compare absentee-owners who entrust their cattle to herders and owners who were managing themselves their cattle herds. The investigated variables included the socioeconomic characteristics of the household head (age, sex, educational level, ethnicity), the type and extent of labour in the household (main activity and source of income, size of the household, cultivated land size, number of owned animals from other species), acquisition mode and characteristics of cattle herds (animal age, sex and breed composition). Subsequently, variables that showed significant differences between the two groups of farmers were considered as potential predictors and submitted to a binary logistic regression analysis using a backward stepwise elimination procedure (Hair et al. 2006) to assess factors influencing farmers' decision to entrust their cattle. The dependent variable (cattle entrustment) is dichotomous and can take the value 1 (yes) with a probability of success $y$, or the value 0 (no) with a probability of failure 1-y. Independent variables or predictors are categorical or continuous. The analysis began with the full model (Eq. 1) that included all potential predictor variables. Variables that were not significant in

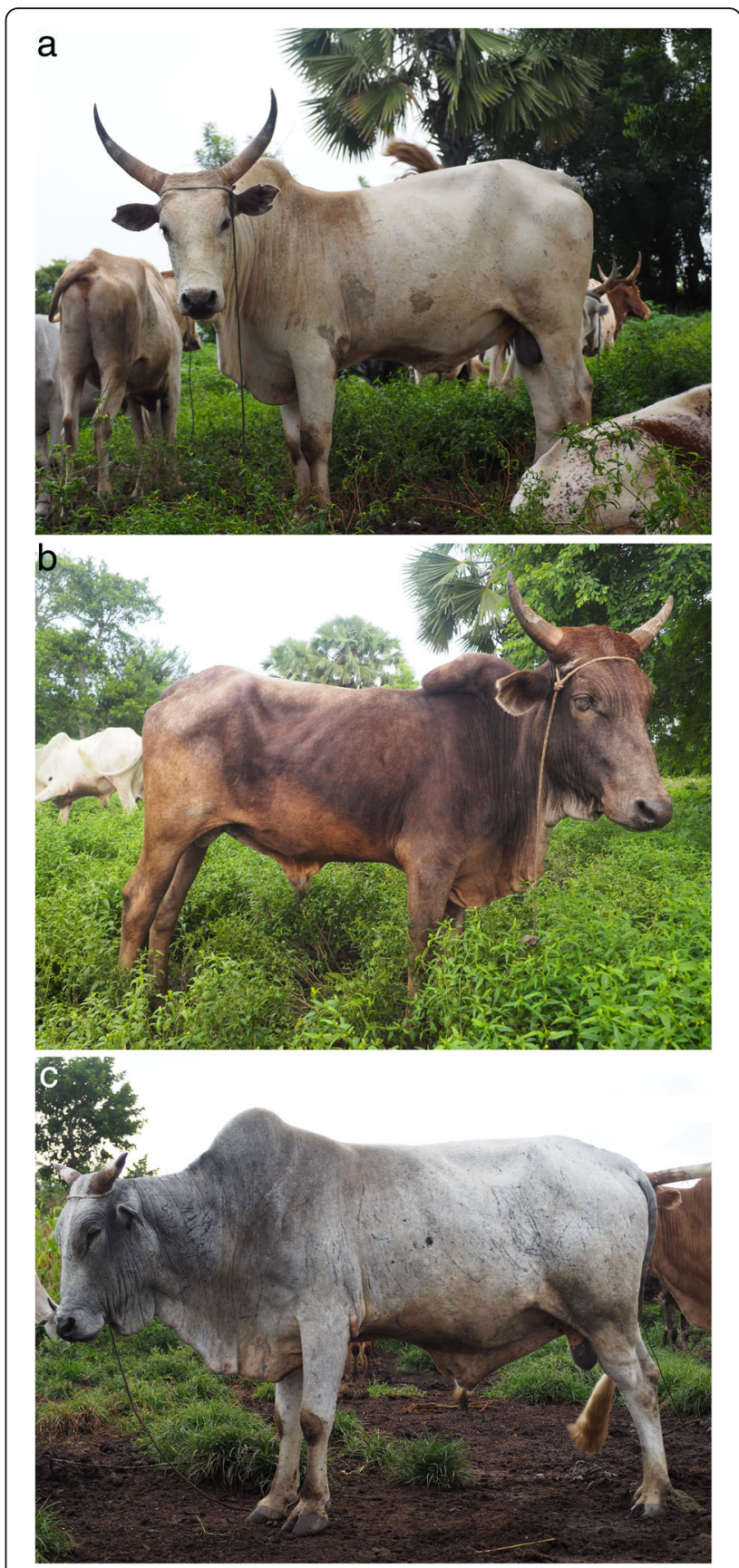

Fig. 3 Examples of Zebu and cross-breeds observed in entrusted herds. a White Fulani bull. b Zebu Azawak. c Goudali cross-breed

predicting the dependent variable were eliminated automatically from the model in an iterative way.

$$
\begin{aligned}
\operatorname{logit}[y(x)] & =\log \left[\frac{y(x)}{1-y(x)}\right] \\
& =\alpha+\beta_{1} x_{1}+\beta_{2} x_{2}+\ldots+\beta_{n} x_{n}
\end{aligned}
$$

where $y$ is the dependent variable, $x$ the predictor or independent variable, $\alpha$ the constant of the equation 
(intercept) and $\beta$ the regression coefficient of the independent variables.

The positive or negative sign of the coefficient $\beta$ indicates the direction of the relationship between a given independent variable $(x)$ and the dependent variable while the odds ratio $\left(e^{\beta}\right)$ gives the relative amount by which the odds of the outcome increases (if odds ratio > 1 ) or decreases (if odds ratio $<1$ ) when the value of the given predictor is increased by 1 unit, all other predictors holding constant. The fit of the final model was assessed by the model chi-square (model $\chi^{2}$ ) and its significance, the goodness-of-fit test of Hosmer and Lemeshow, and the number of cases predicted correctly (Hosmer Jr et al. 2013). Well-fitting models showed significance $(p \leq 0.05)$ on the model $\chi^{2}$ and non-significance $(p>0.05)$ on the goodness-of-fit test of Hosmer and Lemeshow.

\section{Exploring the relation between the practice of cattle entrustment and the management of animal genetic diversity within herds}

Breeding practices and breed composition were compared between entrusted and non-entrusted herds in the Korontiere area, where most of the entrusted herds were found. As previously observed by Dossa and Vanvanhossou (2016), animals from non-entrusted herds are usually left unattended in the grazing areas around homesteads, where they graze together and randomly mate. On the contrary, entrusted herds were always taken to pastures and attended by Fulani herders who generally avoid any contact of their herds with other herds and/or animals encountered in the pastures as a preventive measure against infectious and transmissible diseases. This attitude of the Fulani herders in the study area towards foreign herds is in line with their common value of reserve in personal relations with neighbouring societies, one of the most important components of the pulaaku concept, an ideological construct of the Fulani identity (Breedveld and de Bruijn 1996). As a consequence, there was no contact and exchange of reproducers between entrusted herds and owner-managed herds. However, exchange of reproducers sometimes occurred between herds entrusted to Fulani herders. Therefore, all animals from owner-managed herds that were phenotypically identified by farmers as Somba cattle were considered as one Somba cattle population (communal not entrusted population, CNEP) and all identified Somba animals in entrusted herds considered as another Somba cattle population (communal entrusted population, $\mathrm{CEP}$ ). The effective population size $\left(N_{\mathrm{e}}\right)$ and the rate of inbreeding $(\Delta F)$ were estimated for each of the above-mentioned populations according to Falconer and Mackay (1996) as follows:

$$
\begin{aligned}
& N_{\mathrm{e}}=\frac{4 \times N_{\mathrm{f}} \times N_{\mathrm{m}}}{N_{\mathrm{f}}+N_{\mathrm{m}}} \\
& \Delta F(\%)=\left(\frac{1}{2 N_{\mathrm{e}}}\right) \times 100
\end{aligned}
$$

where $N_{\mathrm{e}}$ is the effective population size, $N_{\mathrm{m}}$ the number of Somba breeding males, $N_{\mathrm{f}}$ the number of Somba breeding females and $\Delta F$ the rate of inbreeding.

An effective population is an ideal population with all individuals mating randomly, equal numbers of sexes, no variation of young per family and no overlapping generations (Lehmkuhl 1984). While inbreeding can be defined as mating related animals, the rate of inbreeding expresses the increase in average inbreeding level in a population from one generation to the next. A rate of inbreeding above $1 \%$ indicates that the increase in homozygosity is greater than $1 \%$ per generation and increases the risk that the population in the long run will not survive. It is therefore widely accepted that the inbreeding rate in domestic animal populations should be kept below $1 \%$ per generation. To achieve this, Franklin (1980) suggested a minimum $N_{\mathrm{e}}$ of 50 breeding animals. However, FAO (1992) notes that the rate of loss of genetic diversity increases dramatically with $N_{\mathrm{e}}$ below 100 . Many approaches have been proposed and updated over time to assess the risk status of livestock breeds (Loftus and Scherf 1993; Gandini et al. 2004; Alderson 2009). The risk status classification of the Somba cattle breed in entrusted and non-entrusted herds was done according to the most recent classification system by FAO (2013), which is based on thresholds either on the number of breeding females or inbreeding rate $(\Delta F)$, and the presence of active conservation programmes (Table 1).

All statistical analyses were done in IBM Statistical Package for Social Sciences (IBM-SPSS for Windows) version 20 and significant differences considered at $p \leq$ 0.05 .

\section{Results and discussion}

Socio-economic characteristics of cattle owners-managers and absentee-owners

The use of extra-household labour in cattle management is not new in the study area (Hall et al. 1995; Bedibete et al. 2007). However, the nearly half of the cattle owners surveyed in this study who were involved in this practice supports its increasing importance. As shown in Table 2, there was a significant relationship $\left(\chi^{2}=65.66\right.$; $p \leq 0.001$ ) between the farm location and the adoption of stock entrustment, this practice being more commonly observed in Korontiere than in Boukombe $(69 \%$ against $14 \%$ of respondents).

No significant difference in the age of household head, the household size and the cultivated land size was 
Table 1 FAO system to assess risk status of livestock breeds (FAO 2013)

\begin{tabular}{lll}
\hline Status & $\begin{array}{l}\text { Conditions on the inbreeding } \\
\text { rate }(\Delta F)\end{array}$ & Other conditions \\
\hline Not at risk & & $\begin{array}{l}\text { Population status is known or existing knowledge give evidence that the breed does not fall } \\
\text { in the other risk categories }\end{array}$ \\
$\begin{array}{l}\text { Vulnerable } \\
\begin{array}{l}\text { Endangered- } \\
\text { maintained }\end{array}\end{array} \quad \begin{array}{l}1 \leq \Delta \leq \Delta F<1 \\
\text { Endangered }\end{array} \quad 1 \leq \Delta F<3$ & $\begin{array}{l}\text { The breed is maintained by an active public conservation programme or within a commercial } \\
\text { or research facility }\end{array}$ \\
Critical-maintained & $\Delta F \geq 3$ & $\begin{array}{l}\text { The breed is maintained by an active public conservation programme or within a commercial } \\
\text { or research facility }\end{array}$ \\
Critical & $\Delta F \geq 3$ &
\end{tabular}

observed between farmers who entrusted their stock and those who did not. However, the decision of cattle owners to entrust or not their animals was particularly influenced by some individual socio-economic characteristics. First, a significant relationship was observed between the ethnicity of the farmer and his adoption of entrustment; herd entrustment was less $(p \leq 0.001)$ common among Otammari people than among other ethnic groups present in the study area. Second, there was a significant relationship $(p \leq 0.05)$ between the cattle owner's education and his adoption of entrustment, whereby owners who can write and read were more likely to entrust their cattle to herders. Likewise, absentee-owners were more likely people who did not experience cattle farming in their childhood and tended to possess significantly higher $(p<0.01)$ numbers of cattle and of other animal species than owners-managers (Table 3). The use of extra-household labour for tending cattle herds was also strongly related to the acquisition mode of the initial stock (Table 4), thereby farmers who

Table 2 Socio-economic characteristics of cattle owners-managers and absentee-owners

\begin{tabular}{|c|c|c|c|c|c|}
\hline & Overall $(n=211)$ & Owners-managers $(n=121)$ & Absentee-owners $(n=90)$ & Chi-square & $p$ value \\
\hline & $(\%)$ & & & & \\
\hline \multicolumn{6}{|l|}{ Sex } \\
\hline Male & 94.3 & 93.4 & 95.6 & 0.452 & 0.501 \\
\hline Female & 5.7 & 6.6 & 4.4 & & \\
\hline Ethnicity & & & & 42.84 & 0.001 \\
\hline Otammari & 74.9 & 91.7 & 52.2 & & \\
\hline Others & 25.1 & 8.3 & 47.8 & & \\
\hline Educational level & & & & 3.760 & 0.052 \\
\hline Non-educated & 80.6 & 85.1 & 74.4 & & \\
\hline Educated & 19.4 & 14.9 & 25.6 & & \\
\hline Cattle keeping since childhood & & & & 15.17 & 0.001 \\
\hline Yes & 55.5 & 66.9 & 40.0 & & \\
\hline No & 44.5 & 33.1 & 60.0 & & \\
\hline Off-farm employment & & & & 1.013 & 0.314 \\
\hline Yes & 11.8 & 9.9 & 14.4 & & \\
\hline No & 88.2 & 90.1 & 85.6 & & \\
\hline Main source of income & & & & 4.853 & 0.088 \\
\hline Crop farming & 69.7 & 63.4 & 77.5 & & \\
\hline Livestock keeping & 24.9 & 29.5 & 19.1 & & \\
\hline \multirow[t]{2}{*}{ Off-farm employment } & 5.5 & 7.1 & 3.4 & & \\
\hline & Means \pm SD & & & & \\
\hline Age of household head (years) & $49.2 \pm 14.29$ & $49.0 \pm 14.63$ & $49.4 \pm 13.93$ & Not applied & 0.757 \\
\hline Household size $(n)$ & $8.1 \pm 3.88$ & $7.9 \pm 3.98$ & $8.3 \pm 3.77$ & & 0.181 \\
\hline Cultivated land size (ha) & $4.0 \pm 2.46$ & $3.5 \pm 1.72$ & $4.2 \pm 2.70$ & & 0.306 \\
\hline
\end{tabular}


Table 3 Number of cattle and other animal species per type of owner

\begin{tabular}{lllll}
\hline & $\begin{array}{l}\text { Overall }(\boldsymbol{n}=\mathbf{2 1 1}) \\
\text { Means } \pm \text { SD }\end{array}$ & Owner-managers $(\boldsymbol{n}=\mathbf{1 2 1})$ & Absentee-owners $(\boldsymbol{n = 9 0 )}$ & $\begin{array}{l}\text { Mann- } \\
\text { Whitney } \\
\boldsymbol{U} \text { test }(\boldsymbol{p}\end{array}$ \\
value $)$
\end{tabular}

${ }^{\mathrm{a}} \mathrm{TLU}$ tropical livestock unit: standardized animal of $250 \mathrm{~kg}$ live weight; 1 cattle $=0.8 \mathrm{TLU} ; 1 \mathrm{pig}=0.2 \mathrm{TLU} ; 1$ sheep/goat $=0.1 \mathrm{TLU}$

purchased their initial stock (52\%) were more likely to entrust their cattle than those who acquired it through inheritance (37\%). In addition, there was a significant relationship $\left(x^{2}=3.96, p<0.001\right)$ between the breed composition of the initial stock and the adoption of entrustment. Herds initially set up with only animals of the indigenous Somba breed were less subjected to entrustment.

Our findings revealed that most practitioners of cattle entrustment were more likely educated people, who had no previous experience in cattle keeping until they decided to purchase their initial stock. The genetic composition of the latter, a mixture of the indigenous smallbodied Somba and non-indigenous large-bodied Zebu, and the large herd sizes, reflects the market orientation of their production. The participation of rural people in more remunerative off-farm activities increases with their education level and decreases with their experience in farming (Akaakohol and Aye 2014; VanWey and Vithayathil 2013). Further, cattle herding requires skills, agility and physical endurance (Moritz 2008). This might explain why inexperienced cattle owners more likely seek, through hiring extra-household labour, the necessary skills required for the management of their large herds and the achievement of their farm economic objectives while devoting their time and energies for other livelihood activities (Majekodunmi et al. 2017; Koura et al. 2015). Accordingly, absentee-owners justified their entrustment practice by the unavailability of children due to their schooling. As observed by Rege et al. (1994), Somba cattle were traditionally taken to pasture by children. This confirms therefore the unavailability of appropriate family labour as a factor affecting the decision to entrust Somba cattle. Following the same logic, the fact that owners from the Otammari ethnic group who have acquired their herds through inheritance continue to ensure themselves the management of their animals points out not only the weight of their experience in this decision (given that they have their childhood roots in cattle herding), but also their commitment to the conservation of the indigenous Somba breed. Indeed, the majority of owner-managers argued against the practice of entrustment as they considered that professional herders take less care of Somba animals than their owners and that milk offtake by professional herders negatively affects calf growth.

\section{Determinants of entrustment practice}

The results of the logistic regression (Table 5) indicate that owners' decision to use extra-household labour force in cattle herding was significantly affected by their ethnicity, the mode of acquisition of the initial stock and the total number of animals (TLU) owned. Without any significant effect $(p>0.01)$, the experience in cattle farming (cattle keeping since childhood) was also identified as a predictor in the final model predicting the decision to entrust Somba cattle. Other factors such as household sex and educational level, cattle herd size, initial stock breeds

Table 4 Initial stock breeds and mode of acquisition by cattle owner-herders and absentee-owners

\begin{tabular}{|c|c|c|c|c|c|}
\hline & $\begin{array}{l}\text { Overall }(n=211) \\
(\%)\end{array}$ & Owners-managers $(n=121)$ & Absentee-owners $(n=90)$ & $\begin{array}{l}\text { Chi- } \\
\text { square }\end{array}$ & $\begin{array}{l}p \\
\text { value }\end{array}$ \\
\hline Mode of acquisition & & & & 31.71 & 0.001 \\
\hline Inheritance & 58.8 & 75.2 & 36.7 & & \\
\hline Purchase & 33.6 & 19.8 & 52.2 & & \\
\hline Others & 7.6 & 5.0 & 11.1 & & \\
\hline Initial stock breeds & & & & 13.960 & 0.001 \\
\hline Somba only & 93.8 & 99.2 & 86.7 & & \\
\hline Somba and others & 6.2 & 0.8 & 13.3 & & \\
\hline
\end{tabular}


Table 5 Logistic regression predicting the practice of entrustment by cattle owners $(n=211)$

\begin{tabular}{|c|c|c|c|c|c|c|}
\hline Predictors & $\beta$ (coefficient) & SE of $\beta$ & Wald's $X^{2}$ & df & $p$ & $e^{\beta i}$ (odds ratio) \\
\hline Constant & 0.065 & 0.537 & 0.015 & 1 & 0.903 & 1.067 \\
\hline Ethnicity $^{a}$ & -1.819 & 0.422 & 18.53 & 1 & 0.000 & 0.162 \\
\hline Cattle keeping since childhood ${ }^{b}$ & -0.394 & 0.361 & 1.194 & 1 & 0.275 & 0.674 \\
\hline Purchase as the mode of acquisition of the initial stock ${ }^{b}$ & 1.142 & 0.382 & 8.951 & 1 & 0.003 & 3.134 \\
\hline Total livestock units owned & 0.162 & 0.056 & 8.477 & 1 & 0.004 & 1.176 \\
\hline Test & & & $x^{2}$ & $d f$ & $p$ & \\
\hline Overall model evaluation & & & 64.894 & 4 & 0.000 & \\
\hline Goodness-of-fit test (Hosmer and Lemeshow) & & & 10.093 & 8 & 0.259 & \\
\hline \multicolumn{7}{|l|}{-2 Log-likelihood 223.044} \\
\hline \multicolumn{7}{|l|}{ Cox and Snell $R^{2}=0.265$} \\
\hline Nagelkerke $R^{2}=0.356$ & & & & & & \\
\hline
\end{tabular}

${ }^{\mathrm{a}} 1=$ Otammari; $0=$ others; ${ }^{\mathrm{b}} 1=$ yes; $0=$ no

and inheritance as mode of acquisition of the initial stock were also tested with no significant effects on the model.

The ethnicity of the owner was revealed as the most significant predictor of his decision to entrust or not his cattle herd $(p<0.001)$. The Otammari ethnicity was negatively related to entrustment $(\beta=-1.8)$, and the likelihood of a farmer to entrust his cattle decreases 0.16 times when he belongs to this socio-cultural group. The model also confirmed that entrustment was more likely practised when the initial stock was acquired through purchase $(\beta=1.1)$ than through inheritance, whereby farmers who acquired their initial stock through purchase were 3.1 times more likely to entrust their cattle than others, cetaris paribus. Furthermore, the results showed that when the number of total animals owned is raised by one unit (one TLU) the odds ratio is 1.18 times as large and therefore the owners are 1.18 times more likely to entrust their cattle. A test of the full model against a constant only model was statistically significant, indicating that the predictors, as a set, reliably distinguished between owner-managers and absenteeowners (model $\chi^{2}=64.894, p<0.001$ with $\mathrm{df}=4$ ). Hosmer and Lemeshow test was not significant $\left(\chi^{2}=10.093\right.$, $p=0.259)$. Prediction success overall was $74.4 \%(60.0 \%$ for absentee-owners and $85.1 \%$ for owner-herders).

The finding that owners from the indigenous Otammari community, keeping the autochthonous Somba cattle breed and recognized as custodians of the autochthonous Somba cattle (Hall et al. 1995), were less likely inclined towards the entrustment practice confirms their attachment to this breed. Indeed, like many breeds worldwide, this breed is named after the ethnic group, the Somba or Otammari which has over multiple decades lived off and cared for it. It is thus the result of many years of selection, techniques and management strategies. Keeping small size herds of this breed appears to be a cultural activity for Otammari people and therefore a way to express their cultural or ethnical identity. Similar cultural importance was reported for the Ankole cattle in Uganda (Ndumu et al. 2008). Hence, Somba cattle-keeping under fortified houses known as tata Somba (Zerbini 2012) is, like other cultural practices, preserved and transmitted from one generation to the next. Furthermore, as the major land use in the Boukombe region is subsistence agriculture, managing small herds of Somba cattle gives Otammari people a great opportunity to use ox-ploughs to cultivate their land and increase their farm's productivity (Okello et al. 2015). Cow dung is also recycled into house building material (Boko 2016). We can thus argue that the high cultural heritage value associated with cattle keeping in the Otammari community limits the expansion of herd entrustment practice. Our findings thus confirm the influence of farmers' socio-cultural characteristics, as well as social norms, on changes or perpetuity in animal husbandry practices as acknowledged by Lémery et al. (2005) and Manoli et al. (2010). However, the increasing importance of cattle entrustment by absentee-owners, who are only interested in the cash benefits derived from their entrusted herds, reveals a changing function of cattle husbandry in the study area. As many rural and urban African households are increasingly using this activity as an entry point into the cash economy, they increase their cattle herd size and change its composition and management strategies to fit to their economic objectives (Giller et al. 2011; Baudron et al. 2014).

\section{Implications of the entrustment practice for the management of animal genetic diversity Herds' breed composition and structure}

There was a significant relationship between the herd status (entrusted or owner-managed) and its breed composition $\left(\chi^{2}=10.012 ; p=0.040\right)$. Most $(97 \%)$ of herds managed by their owners were of Somba cattle whereas 
in $33 \%$ of entrusted herds, Somba cattle were mixed with other breeds, for instance Borgou, Zebu or their crosses. Likewise, entrusted herds had significantly greater sizes $(p<0.001)$ than owner-managed herds $(55.8 \pm 20.87$ against $4.9 \pm 5.35$ heads). Further, the proportions of adult animals (mature bulls, oxen and cows) were significantly higher in non-entrusted herds while young animals (calves and bull-calves) dominated in entrusted herds.

There was a significant relationship $\left(\chi^{2}=20.226 ; p=\right.$ 0.01 ) between the herd type (owner-managed or entrusted) and the presence of breeding males in the herd. Almost all entrusted herds $(83 \%)$ had at least one bull whereas there was a total absence of a single bull in $65 \%$ of owner-managed herds. However, in the remaining $35 \%$ of owner-managed herds where they existed, the breeding males were all of Somba breed whereas $27 \%$ of the bulls identified in entrusted herds were of other non-local breeds (either Zebu or Borgou). Irrespective of the herd type, the proportion of oxen in the herd was higher than that of bulls and all oxen found in both types of herd were of indigenous Somba cattle.

\section{Effective population sizes and inbreeding rates of the Somba cattle populations}

Number of Somba breeding males $\left(N_{\mathrm{m}}\right)$ and females $\left(N_{\mathrm{f}}\right)$, as well as estimates of effective population size $\left(N_{\mathrm{e}}\right)$ are given in Table 6 . The values of all these genetic parameters were greater for the communal entrusted population (CEP) than for the communal non-entrusted population (CNEP). In contrast, the estimated inbreeding rates $\Delta F$ were relatively lower in the CEP and reached the limit of $1 \%$ in the CNEP.

\section{Entrustment practice and sustainable management of Somba cattle breed}

In the study area, extra-household labour for herding was remunerated either in cash or/and in kind. Additionally, in most cases, the totality of the milk offtake from entrusted herd cows was at the discretion of the herder and his household. Milk represents thus a regular source of income for the entrustee's household. Absentee-owners and owner-managers are non-Fulani and have little interest in milk. Similar disinterest in milk has been reported in northern Ghana (Tonah 2012). It further explains why, unlike in herds managed by their owners who are all not from the Fulani socio-cultural group, the management strategy in herds entrusted to Fulani herdsmen was more focused on providing milk for the herdsmen and their family (Dossa and Vanvanhossou 2016).

While an absentee herd owner's objective is to maximize herd growth, a high rate of income through high herd milk productivity is certainly one, if not the most important, motivation of the herdsman to whom the herd is entrusted. The herd production is then oriented towards the herdsman's objectives as the herd remains at his homestead. A similar observation was made by Toure et al. (2015) in Mali. Yet, both the motivation of the herder for milk and of the owner for economic profitability through high herd growth rate certainly justify the significantly higher presence of Zebus and other non-local breeds in entrusted than in owner-managed herds as observed in this study. Moritz et al. (2011) argue that motivation for cross-breeding often comes from the Fulani herdsmen. They are aware that the genetic make-up of the herd influences its milk and growth performances (Boutrais 2007), and recent studies have provided evidence that the large-bodied West African Zebus and their crosses give higher milk yield than small-bodied West African taurine breeds (Coffie et al. 2015; Hiernaux et al. 2017).

In entrusted herds, Zebus and their crosses are usually kept together with the indigenous shorthorn taurine Somba breed. As a consequence, herders did not have full control over mating and cross-breeding, since they could not fully control the mating behaviour of individual animals in the herds. It is thus the admixture of Zebus breeds in Somba breed resulting from indiscriminate cross-breeding which, like in other breeds, threatens the genetic pool of Somba cattle populations kept in entrusted herds (Mwai et al. 2015). Furthermore, although a nucleus of Somba cows still remained in these herds, their male offsprings (bull and calves) were often castrated. This practice, also reported for the South African Nguni cattle by MacNeil and Matjuda (2007) and Scholtz et al. (2008), puts the native Somba breed at risk of

Table 6 Effective population sizes and inbreeding rates of the Somba cattle populations in Korontiere

\begin{tabular}{lll}
\hline Parameters & Communal non-entrusted population (CNEP) & Communal entrusted population (CEP) \\
\hline Number of Somba breeding males $\left(N_{\mathrm{m}}\right)$ & 16 & 21 \\
Number of Somba breeding females $\left(N_{\mathrm{f}}\right)$ & 58 & 145 \\
Total Somba breeding population $\left(N=N_{\mathrm{m}}+N_{\mathrm{f}}\right)$ & 74 & 166 \\
Effective population size $\left(N_{\mathrm{e}}\right)$ & 50.16 & 73.37 \\
Estimated inbreeding rates per generation $\left(\Delta F_{,} \%\right)$ & 1.00 & 0.68 \\
\hline
\end{tabular}


complete absorption by Zebus and their crosses in entrusted herds.

In other respects, the owner-managed Somba population is threatened even in herds constituted of only Somba animals for two major reasons: its small herd sizes and estimated communal effective population size $\left(N_{\mathrm{e}}\right)$. The latter was almost at the threshold value of 50 recommended to maintain genetic diversity in the long term while the number of breeding males $\left(N_{\mathrm{m}}\right)$ was less than 20 and that of breeding females $\left(N_{\mathrm{f}}\right)$ less than 100 . Consequently, the estimated inbreeding rate was very high (1\%). Given that $\Delta F$, as calculated from a demographic model in the absence of pedigree information, might be significantly underestimated (Blackwell et al. 1995), we might consider that the genetic diversity in the Somba breed is at high risk of reduction in ownermanaged herds.

Systematic castration certainly explains the complete absence of sires in many herds and thus the low $N_{\mathrm{m}}$. This leads to reduced chance of mating, low cow fecundity rates and decreasing total number of the breeding population $\left(N_{\mathrm{m}}+N_{\mathrm{f}}\right)$. The values of $N_{\mathrm{m}}$ and $N_{\mathrm{f}}$ as well as the estimate values of $N_{\mathrm{e}}$ and $\Delta F$ were slightly higher in entrusted herds probably due to pooling small herds from different owners which increased random mating while reducing risks of inbreeding (Mwambene et al. 2012). This finding suggests that owner-managed Somba cattle herds are more prone to inbreeding effects than mixed-breed entrusted herds. Given that no active conservation programme is currently targeting this indigenous breed, it could be considered as threatened in both entrusted and owner-managed herds according to the FAO system (FAO 2013). But further genomic investigations are requested to precisely assess the actual status of this breed.

In owner-managed herds, control of inbreeding through the increase of the proportion of breeding individuals should be given high priority. This could be achieved by raising awareness among herder-managers about the necessity to improve their general management practices (feeding, health control, reproduction) and through the development of community-based breeding strategies (Wurzinger et al. 2011; Haile et al. 2013). The general premise is that improving the animal diets (Diskin and Kenny 2014) and reducing their mortality and morbidity will improve herd reproductive performances and thus herd growth. Moreover, community-based breeding schemes will increase collaboration between farmers and foster exchange of knowledge. Subsequently, the creation of a communal reproducers pool may help in reducing inbreeding through organized bull selection and exchanges or through well-designed breeding strategies (Wollny 2003; Wurzinger et al. 2011). In the absence of any sound breed improvement programme, indiscriminate crossbreeding and inter-mixing of breeds will inevitably continue to be a serious threat to the adaptive and specific traits of the Somba breed in entrusted herds. In addition, the sustainability of several breeding and cross-breeding strategies requires a continuous supply of pure genetic material, indicating the importance of conserving the Somba breed for further and sustainable uses (Leroy et al. 2016). Cross-breeding with other breeds may represent an opportunity to reduce inbreeding and upgrade the indigenous Somba cattle for either the enhancement of their adaptive potential to climate changes or the improvement of their productive performances. Nevertheless, genetic and advanced genomic studies are required to design suitable breeding strategies for local cattle populations including the identification of suitable breeds for cross-breeding and proportion of admixture to meet farmers' interests and environmental requirements (Wollny 2003; Wurzinger et al. 2014; Marshall et al. 2019). Development of programmes towards improved use and conservation of the indigenous Somba breed should take into account the herd type specificities highlighted in the present study.

\section{Conclusion}

Cattle owner-managers and absentee-owners pursue different production objectives. While tending cattle is rooted in the childhood of the former, and therefore still fulfils significant social and cultural functions among them, it is being increasingly used as an economic venture by the latter. The results of our study show that owner's socio-cultural origin, the mode of acquisition of the initial stock and the herd size were the most important factors that determine whether an owner entrusts his stock or managed it himself. Owner-managers tended to keep the indigenous breed to which they are culturally attached. But this valuable local genetic resource is threatened in these herds by small effective population sizes and high inbreeding rates. Stock entrustment favours livelihood diversification and cattle enterprise development, but it exposes the local breed to high risk of indiscriminate cross-breeding and inter-mixing of breeds. As this practice is growing in importance in African pastoral systems, our findings have important policy implications for the development and/or improvement of strategies towards a better use and conservation of indigenous African cattle genetic resources. Taking into consideration the pros and cons of the two management practices highlighted in this study, such strategies should start with increasing awareness among herd managers about the need to minimize inbreeding and indiscriminate cross-breeding and persuading them to adopt improved herd management practices, especially in animal health, feeding and reproduction. 


\section{Abbreviations}

CEP: Communal entrusted population; CNEP: Communal non-entrusted population; N: Total breeding population; $N_{\mathrm{e}}$ : Effective population size; $N_{f}$ : Number of breeding females; $N_{\text {m }}$ : Number of breeding males; SD: Standard deviation; SE: Standard error; TLU: Tropical livestock unit; $\Delta F$ : Estimated inbreeding rates per generation; $X^{2}$ : Chi-square

\section{Acknowledgements}

The authors express their sincere gratitude to all participating farmers and to the officers of the Agricultural Extension Service of Boukombe for their valuable help and cooperation during the field work. They also thank anonymous reviewers for their valuable comments and suggestions.

\section{Authors' contributions}

LHD and SFUV designed the research. SFUV collected the data. SFUV and BIK analysed the data and wrote the manuscript. LHD reviewed and edited the manuscript. All the authors read and approved the final manuscript.

\section{Funding}

This study was financially supported by the VolkswagenStiftung, Hannover, Germany, Grant No. Az-94829.

\section{Availability of data and materials}

The datasets used and/or analysed during the current study are available from the corresponding author on reasonable request.

\section{Declarations}

\section{Ethics approval and consent to participate}

Authorization from the village authorities and informed consent from farmers and cattle breeders were obtained prior to the interviews.

\section{Consent for publication}

\section{Not applicable}

\section{Competing interests}

The authors declare that they have no competing interests.

\section{Author details}

${ }^{1}$ Ecole des Sciences et Techniques de Production Animale Faculté des Sciences Agronomiques, Université d'Abomey-Calavi, 03 BP 2819, Cotonou, Benin. ${ }^{2}$ Institute of Animal Breeding and Genetics, Justus-Liebig-University of Gießen, Ludwigstraße 21 b, 35390, Gießen, Germany. ${ }^{3}$ Ecole de Gestion et d'Exploitation des Systèmes d'Elevage, Université Nationale d'Agriculture, BP 43, Kétou, Benin.

Received: 27 February 2020 Accepted: 7 December 2020

Published online: 01 May 2021

\section{References}

Adégbidi, A., E. Gandonou, and R. Oostendorp. 2004. Measuring the productivity from indigenous soil and water conservation technologies with household fixed effects: A case study of hilly mountainous areas of Benin. Economic Development and Cultural Change 52 (2): 313-346. https://doi.org/10.1086/3 81018.

Akaakohol, M.A., and G.C. Aye. 2014. Diversification and farm household welfare in Makurdi, Benue State, Nigeria. Development Studies Research 1 (1): 168-175. https://doi.org/10.1080/21665095.2014.919232.

Alderson, L. 2009. Breeds at risk: Definition and measurement of the factors which determine endangerment. Livestock Science 123: 23-27. https://doi. org/10.1016/j.livsci.2008.10.001

Bagamba, F., K. Burger, and A. Kuyvenhoven. 2009. Determinant of smallholder farmer labour allocation decisions in Uganda. In IFPRI discussion paper 00887, Environment and Production Technology Division. Washington DC: IFPRI.

Baudron, F., M. Jaleta, O. Okitoi, and A. Tegegne. 2014. Conservation agriculture in African mixed crop-livestock systems: Expanding the niche. Agriculture, Ecosystems and Environment 187: 171-182. https://doi.org/10.1016/j.agee.2 013.08.020.

Bedemo, A., K. Getnet, B. Kassa, and S.P.R. Chaurasia. 2013. Off-farm labor supply decision of adults in rural Ethiopia: Double hurdle approach. Journal of Agricultural Economics and Development 2 (4): 154-165.
Bedibete, B., A. Kossi, and B. Habre. 2007. Tamberma's Somba cattle breed at risk of extinction in Togo. In People and animals: Traditional livestock keepers. Guardians of domestic animal diversity, ed. K.A. Tempelman and R.A. Cardellino, 79-83. Rome: Food and Agriculture Organization.

Benjamin, C., A. Corsi, and H. Guyomard. 1996. Modelling labour decisions of French agricultural households. Applied Economics 28 (12): 1577-1589. https://doi.org/10.1080/000368496327552.

Benjamin, C., and A. Kimhi. 2006. Farm work, off-farm work, and hired farm labour: Estimating a discrete-choice model of French farm couples' labour decisions. European Review of Agricultural Economics 33 (2): 149-171. https:// doi.org/10.1093/erae/jbl002.

Berthier, D., S.F. Brenière, R. Bras-Gonçalves, J.L. Lemesre, V. Jamonneau, P. Solano, V. Lejon, S. Thévenon, and B. Bucheton. 2016. Tolerance to trypanosomatids: A threat, or a key for disease elimination? Trends in Parasitology 32 (2): 157168 https://doi.org/10.1016/j.pt.2015.11.001.

Blackwell, B.F., P.D. Doerr, J.M. Reed, and J.R. Walters. 1995. Inbreeding rate and effective population size: A comparison of estimates from pedigree analysis and a demographic model. Biological Conservation 71 (3): 299-304. https:// doi.org/10.1016/0006-3207(94)00050-Z.

Blanc, M., E. Cahuzac, B. Elyakime, and G. Tahar. 2008. Demand for on-farm permanent hired labour on family holdings. European Review of Agricultural Economics 35 (4): 493-518. https://doi.org/10.1093/erae/jbn032.

Blench, R. 1999. Traditional livestock breeds: Geographical distribution and dynamics in relation to the ecology of West Africa. In Working paper 122. London: Overseas Development Institute.

Boko, H.N.K. 2016. Traditional management systems: A case study of housing in Otammari land and Ganvié in Benin. In Traditional management systems at heritage sites in Africa, ed. G.O. Abungu, N. Ndlovu, F.E.I. Thiombiano, J. Zulu, and S. Varissou, 51-58. Midrand: African World Heritage Fund.

Boutrais, J. 2007. The Fulani and cattle breeds: Crossbreeding and heritage strategies. Africa 77 (11): 18-36. https://doi.org/10.3366/afr.2007.77.1.18.

Breedveld, A., and M. de Bruijn. 1996. L'image des Fulbe: Analyse critique de la construction du concept de pulaaku. Cahiers d'Etudes Africaines 144 (36-4): 791-821.

Breusers, M. 2014. Friendship and spiritual parenthood among the Moose and the Fulbe in Burkina Faso. Friendship, Descent and Alliance in Africa: Anthropological Perspectives ed. M. Guichard, T. Grätz, and Y. Diallo, 10: 74-96. Oxford: Berghahn.

Coffie, I., S.Y. Annor, J.K. Kagya-Agyemang, and F.R.K. Bonsu. 2015. Effect of breed and non-genetic factors on milk yield of dual-purpose cattle in Ashanti Region, Ghana. Livestock Research for Rural Development 27: 134 http://www. Irrd.org/lrrd27/7/coff27134.htm. Accessed 03 Oct 2019.

Dafinger, A. 2013. The economics of ethnic conflict: The case of Burkina Faso. Woodbridge: James Currey.

Darpeix, A., C. Bignebat, and P. Perrier-Cornet. 2014. Demand for seasonal wage labour in agriculture: What does family farming hide? Journal of Agricultural Economics 65 (1): 257-272. https://doi.org/10.1111/1477-9552.12019.

De Haan, L. 1997. Agriculteurs et éleveurs au Nord du Bénin : Ecologie et genres de vie. Paris: Karthala Editions.

Diskin, M.G., and D.A. Kenny. 2014. Optimising reproductive performance of beef cows and replacement heifers. Animal 8 (s1): 27-39. https://doi.org/10.1017/ S175173111400086X.

Donnellan, T., K. Hanrahan, and T. Hennessy. 2012. Defining an institutional framework for the labour market. In Factor Markets. Working Essays. Brussels: Centre for European Policy Studies (CEPS).

Dossa, L.H., and F.U.S. Vanvanhossou. 2016. The indigenous Somba cattle of the hilly Atacora region in North-West Benin: Threats and opportunities for its sustainable use. Tropical Animal Health and Production 48: 349-359. https:// doi.org/10.1007/s11250-015-0958-5.

Duguma, B., A. Tegegne, and B.P. Hegde. 2012. Smallholder livestock production system in Dandi district, Oromia Regional State, Central Ethiopia. Global Veterinaria 8 (5): 472-479.

Dupraz, P., A. van den Brink, and U. Latacz-Lohmann. 2010. Direct income support and cross-compliance. In EU Policy for agriculture, food and rural areas, ed. A. Oskam, G. Meester, and H. Silvin. 351-362. Wageningen, the Netherlands: Wageningen Academic Publishers.

Falconer, D.S., and T.F. Mackay. 1996. Introduction to quantitative genetics. 4th ed. New York: Longman.

FAO. 1992. Monitoring AnGR and criteria for prioritization of breeds. Rome: FAO.

FAO. 2007. In The state of the world's animal genetic resources for food and agriculture, ed. B. Rischkowsky and D. Pilling. Rome. http://www.fao. org/3/a-a1250e.pdf. Accessed 17 Nov 2020. 
FAO. 2013. In vivo conservation of animal genetic resources. In FAO Animal Production and Health Guidelines N ${ }^{\circ} 14$. Rome: FAO.

FAO. 2015. The second report on the state of the world's animal genetic resources for food and agriculture. In FAO Commission on Genetic Resources for Food and Agriculture Assessments, ed. B.D. Scherf and D. Pilling. Rome. http://www.fao.org/3/i4787e/i4787e.pdf. Accessed 17 Nov 2020.

Franklin, I.R. 1980. Evolutionary change in small populations. In Conservation biology: An evolutionary-ecological perspective, ed. M.E. Soule and B.A. Wilcox, 135-149. Sunderland (MA): Sinauer.

Gandini, G., L. Ollivier, B. Danell, O. Distl, A. Georgudis, E. Groeneveld, E. Martiniuk, J. van Arendonk, and J. Woolliams. 2004. Criteria to assess the degree of endangerment of livestock breeds in Europe. Livestock Production Science 91: 173-182. https://doi.org/10.1016/j.livprodsci.2004.08.001.

Gbaguidi, A., R. Batcho, A. Tidjani, T. Yokossi, and C. Wammasse. 2006. Rapport du recensement et du diagnostic sur l'élevage de la race bovine Somba dans la commune de Boukombé. In CeRPA Atacora-Donga, DRC / Natitingou, Rapport Projet PAMRAD, CeRPA Atacora-Donga, Natitingou, Benin.

Giller, K.E., M. Corbeels, J. Nyamangara, B. Triomphe, F. Affholder, E. Scopel, and P. Tittonell. 2011. A research agenda to explore the role of conservation agriculture in African smallholder farming systems. Field Crops Research 124 (3): 468-472. https://doi.org/10.1016/j.fcr.2011.04.010.

Haile, A., T. Mirkena, G. Duguma, M. Wurzinger, B. Rischkowsky, M. Tibbo, M. Okeyo, and J. Sölkner. 2013. Community based sheep breeding programs: Tapping into indigenous knowledge. Livestock Research for Rural Development 25 (12). http://www.Irrd.cipav.org.co//rrd25/12/hail25219.htm. Accessed 10 Oct 2019.

Hair, J.F., W.C. Black, B.J. Babin, R.E. Anderson, and R.L. Tatham. 2006. Multivariate data analysis. 6th ed. Upper Saddle River, New Jersey: Prentice Hall.

Hall, S., L. Gnaho, and C. Meghen. 1995. Une enquête sur la race bovine Somba. Revue d'élevage et de Médecine Vétérinaire des Pays Tropicaux 48: 77-83.

Hiernaux, P., K. Adamou, A. Zezza, A.A. Ayantunde, and G. Federighi. 2017. Milk offtake of cows in smallholder farms of semiarid Sahel: Low yields with high value. Revue d'élevage et de Médecine Vétérinaire des Pays Tropicaux 69 (4): 143-153.

Hindar, K. 2001. Introductions at the level of genes and populations. In Invasive Species and Biodiversity Management, ed. O.T. Sandlund, P.J Schei, and A. Viken, 149-161. The Netherlands: Kluwer Academic publisher.

Hosmer, D.W., Jr., S. Lemeshow, and R.X. Sturdivant. 2013. Applied logistic regression. 3rd ed. New York: John Wiley \& Sons.

Houessou, S.O., L.H. Dossa, R.V.C. Diogo, M.C. Ahozonlin, M. Dahouda, and E. Schlecht. 2019. Confronting pastoralists' knowledge of cattle breeds raised in the extensive production systems of Benin with multivariate analyses of morphological traits. PLoS One 14 (9): 1-19. https://doi.org/10.1371/journal. pone.0222756.

INSAE (Institut National de la Statistique et de l'Analyse Économique). 2016. Principaux indicateurs socio-démographiques et économiques ( $\mathrm{RGPH}-4$ 2013). In Direction des Etudes démographiques. Cotonou (Benin): INSAE.

Kamuanga, M., K. Tano, K. Pokou, G. d'leteren, C. Mugalla, and J. Somda. 2006. Farmers' preferences for cattle breeds and prospects for improvement in West Africa. In Livestock Agriculture in West and Central Africa: Achievements in the past 25 years, challenges ahead and the way forward, ed. A. Schoenefeld et al., 92-94. ITC-CIRDES-CTA.

Koffi, C.K., H. Djoudi, and D. Gautier. 2017. Landscape diversity and associated coping strategies during food shortage periods: Evidence from the SudanoSahelian region of Burkina Faso. Regional Environmental Change 17 (5): 1369 1380. https://doi.org/10.1007/s10113-016-0945-z.

Koura, B.I., H. Dedehouanou, H.L. Dossa, B.V. Kpanou, F. Houndonougbo, P. Houngnandan, G.A. Mensah, and M. Houinato. 2015. Determinants of croplivestock integration by small farmers in Benin. International Journal of Biological and Chemical Sciences 9 (5): 2272-2283. https://doi.org/10.4314/ ijbcs.v9i5.2.

Lehmkuhl, J.F. 1984. Determining size and dispersion of minimum viable populations for land management planning and species conservation. Environmental Management 8 (2): 167-176. https://doi.org/10.1007/BF01 866938.

Lémery, B., S. Ingrand, B. Dégrange, and B. Dedieu. 2005. Agir en situation d'incertitude : le cas des éleveurs de bovins allaitants. Economie Rurale 288: 57-69.

Leroy, G., R. Baumung, P. Boettcher, B. Scherf, and I. Hoffmann. 2016. Sustainability of crossbreeding in developing countries; definitely not like crossing a meadow... Animal 10 (2): 262-273. https://doi.org/10.1017/S1751 $73111500213 X$
Little, P.D. 1992. The elusive granary: Herder, farmer, and state in northern Kenya. Cambridge: University Press.

Loftus, R., and B. Scherf. 1993. World watch list for domestic animal diversity. 1st ed. Rome: Food and Agriculture Organization.

Lont, H., and O. Hospes. 2004. Livelihood and microfinance. In Anthropological and sociological perspectives on savings and debt. Delft: Eburon Academic Publishers.

MacNeil, M.D., and L.E. Matjuda. 2007. Breeding objectives for Angus and Charolais specialized sire lines for use in the emerging sector of South African beef production. South African Journal of Animal Science 37: 1-10. https://doi.org/10.4314/sajas.v37i1.4019.

Majekodunmi, A.O., C. Dongkum, T. Langs, A.P. Shaw, and S.C. Welburn. 2017. Shifting livelihood strategies in northern Nigeria-extensified production and livelihood diversification amongst Fulani pastoralists. Pastoralism 7 (1): 19. https://doi.org/10.1186/s13570-017-0091-3.

Manoli, C., A. Ickowicz, and B. Dedieu. 2010. Livestock farming systems and local development: A review of the multiple dimensions of "territory" in livestock science. In 9th European IFSA symposium, 4-7 July 2010. Vienna: Austria.

Marshall, K., J.P. Gibson, O. Mwai, J.M. Mwacharo, A. Haile, T. Getachew, R. Mrode, and S.J. Kemp. 2019. Livestock genomics for developing countries-African examples in practice. Frontiers in Genetics 10: 1-13. https://doi.org/10.3389/ fgene.2019.00297.

Moritz, M. 2008. A critical examination of honor cultures and herding societies in Africa. African Studies Review 51 (2): 99-117. https://doi.org/10.1353/arw.0. 0052.

Moritz, M. 2012a. Individualization of livestock ownership in Fulbe family herds: The effects of pastoral intensification and Islamic renewal. In Who owns the stock? Collective and multiple forms of property in animals, ed. A. Khazanov and G. Schlee, 193-214. Berghahn: Oxford.

Moritz, M. 2012b. Pastoral intensification in West Africa: Implications for sustainability. Journal of the Royal Anthropological Institute 18 (2): 418-438. https://doi.org/10.1111/j.1467-9655.2012.01750.x.

Moritz, M., I.M. Hamilton, A.J. Yoak, P. Scholte, J. Cronley, P. Maddock, and H. Pi. 2015. Simple movement rules result in ideal free distribution of mobile pastoralists. Ecological Modelling 305: 54-63. https://doi.org/10.1016/j. ecolmodel.2015.03.010.

Moritz, M., K. Ritchey, and S. Kari. 2011. The social context of herding contracts in the Far North Region of Cameroon. The Journal of Modern African Studies 49 (2): 263-285. https://doi.org/10.1017/S0022278X11000048.

Murphy, D.J. 2015. From kin to contract: Labor, work and the production of authority in rural Mongolia. Journal of Peasant Studies 42 (2): 397-424. https://doi.org/10.1080/03066150.2014.974569.

Mwai, O., O. Hanotte, Y.J. Kwon, and S. Cho. 2015. African indigenous cattle: unique genetic resources in a rapidly changing world. Asian-Australasian Journal of Animal Sciences 28 (7): 911-921. https://doi.org/10.5713/ajas15. 0002R.

Mwambene, P.L., A.M. Katule, S.W. Chenyambuga, and P.A.A. Mwakilembe. 2012. Fipa cattle in the southwestern highlands of Tanzania: Desired attributes, breeding practices and productive performance. Animal Genetic Resources 51: 45-56. https://doi.org/10.1017/\$2078633612000124.

Ndumu, D.B., R. Baumung, O. Hanotte, M. Wurzinger, M.A. Okeyo, H. Jianlin, H. Kibogo, and J. Sölkner. 2008. Genetic and morphological characterisation of the Ankole Longhorn cattle in the African Great Lakes region. Génétique Selection Evolution 40: 467-490. https://doi.org/10.1186/1297-9686-40-5-467.

Nimbkar, C., J. Gibson, M. Okeyo, P. Boettcher, and J. Soelkner. 2008. Sustainable use and genetic improvement. Animal Genetic Resources Information 42: 4965. https://doi.org/10.1017/S1014233900002558.

Nin-Pratt, A., B. Yu, and S. Fan. 2010. Comparisons of agricultural productivity growth in China and India. Journal of Productivity Analysis 33 (3): 209-223. https://doi.org/10.1007/s11123-009-0156-4.

Okello, W.O., D. Muhanguzi, E.T. MacLeod, S.C. Welburn, C. Waiswa, and A.P. Shaw. 2015. Contribution of draft cattle to rural livelihoods in a district of southeastern Uganda endemic for bovine parasitic diseases: An economic evaluation. Parasites \& Vectors 8: 571. https://doi.org/10.1186/s13071-015-11 91-9.

Oksen, P. 2001. Agricultural expansion and animal husbandry in a West African savannah environment. Policy, property and production in the West African Sahel. In Understanding natural resources management, ed. T.A. Benjaminsen and C. Lund, 303-331. Uppsala: Nordiska Afrikainstitutet.

Omotesho, K.F., A. Muhammad-Lawal, and D.E. Ismaila. 2014. Assessment of hired labour use and food security among rural farming households in Kwara 
State, Nigeria. The Journal of Agricultural Science 59 (3): 353-361. https://doi. org/10.2298/JAS14033530.

Rege, J. E.O., G. S. Aboagye, and C. L. Tawah. 1994. Shorthorn cattle of West and Central Africa, II: ecological settings, utility, management and production systems. World Animal Review 78 (1): 14-21.

Rege, J.E.O., and J.P. Gibson. 2003. Animal genetic resources and economic development: Issues in relation to economic valuation. Ecological Economics 45 (3): 319-330. https://doi.org/10.1016/S0921-8009(03)00087-9.

Roumasset, J., and S.H. Lee. 2007. Labor: Decisions, contracts and organization. Handbook of Agricultural Economics 3: 2705-2740. https://doi.org/10.1016/S1 574-0072(06)03052-0.

Scheper, C., M. Bohlouli, K. Brügemann, C. Weimann, S.F.U. Vanvanhossou, S. König, and L.H. Dossa. 2020. The role of agro-ecological factors and transboundary transhumance in shaping the genetic diversity in four indigenous cattle populations of Benin. Journal of Animal Breeding and Genetics 137 (6): 622-640. https://doi.org/10.1111/jbg.12495.

Scholtz, M.M., J. Bester, J.M. Mamabolo, and K.A. Ramsay. 2008. Results of the national cattle survey undertaken in South Africa, with emphasis on beef. Applied Animal Husbandry and Rural Development 1: 1-9.

Tonah, S. 2012. Fulbe pastoralists and the changing property relations in northern Ghana. In Who owns the stock? Collective and multiple forms of property in animals, ed. A. Khazanov and G. Schlee, 231-246. Oxford: Berghahn.

Toulmin, C. 1992. Herding contracts: For better or worse. ILEIA Newsletter 8 (3): 89.

Toure, A., N. Moula, A. Kouriba, B. Traore, P. Leroy, and N. Antoine-Moussiaux. 2015. Dairy farms typology and management of animal genetic resources in the peri-urban zone of Bamako (Mali). Journal of Agriculture and Rural Development in the Tropics and Subtropics 116 (1): 37-47.

Turner, M.D. 1999. Labor process and the environment: The effects of labor availability and compensation on the quality of herding in the Sahel. Human Ecology 27 (2): 267-296. https://doi.org/10.1023/A:1018725327873.

Turner, M.D., and P. Hiernaux. 2008. Changing access to labor, pastures, and knowledge: The extensification of grazing management in Sudano-Sahelian West Africa. Human Ecology 36 (1): 59-80. https://doi.org/10.1007/s10745007-9149-y

Turner, M.D., J.G. McPeak, and A. Ayantunde. 2014. The role of livestock mobility in the livelihood strategies of rural peoples in semi-arid West Africa. Human Ecology 42 (2): 231-247. https://doi.org/10.1007/s10745-013-9636-2.

UNEP (United Nations Environmental Programme). 1992. Convention on biological diversity. UNEP, Environmental Law and Institutions Programme Activity Centre, Nairobi. https://www.cbd.int/doc/legal/cbd-en.pdf. Accessed 17 Nov 2020.

VanWey, L., and T. Vithayathil. 2013. Off-farm work among rural households: A case study in the Brazilian Amazon. Rural Sociology 78 (1): 29-50. https://doi. org/10.1111/j.1549-0831.2012.00094.x

Wollny, C.B.A. 2003. The need to conserve farm animal genetic resources in Africa: Should policy makers be concerned? Ecological Economics 45 (3): 341 351. https://doi.org/10.1016/50921-8009(03)00089-2.

Wurzinger, M.. T. Mirkena, and J. Sölkner. 2014. Animal breeding strategies in Africa: Current issues and the way forward. Journal of Animal Breeding and Genetics 131 (5): 327-328. https://doi.org/10.1111/jbg.12116.

Wurzinger, M., J. Sölkner, and L. Iñiguez. 2011. Important aspects and limitations in considering community-based breeding programs for low-input smallholder livestock systems. Small Ruminant Research 98 (1-3): 170-175. https://doi.org/10.1016/j.smallrumres.2011.03.035.

Zerbini, L. 2012. L'architecture du nord-ouest du Bénin. Entre construction et interprétation d'un savoir. Les Nouvelles de L'archéologie (128): 16-21. https:// doi.org/10.4000/nda.1621.

\section{Publisher's Note}

Springer Nature remains neutral with regard to jurisdictional claims in published maps and institutional affiliations.

\section{Submit your manuscript to a SpringerOpen ${ }^{\circ}$ journal and benefit from:}

- Convenient online submission

- Rigorous peer review

- Open access: articles freely available online

- High visibility within the field

- Retaining the copyright to your article

Submit your next manuscript at $\boldsymbol{\nabla}$ springeropen.com 